\title{
An assessment of Macro-benthic Invertebrates abundance and distribution in Rezukhal estuary Cox's Bazar, Bangladesh with Special Reference to several Hydrological Parameters.
}

\author{
"Md. Tarikul Islam ${ }^{1}$, Md. Shafiqul Islam², Md. Mohidul Islam ${ }^{3}$, Alam Pervez ${ }^{4}$ \\ ${ }^{1}$ Bangladesh Oceanographic Research Institute, Ramu, Cox's Bazar \\ ${ }^{2,4}$ Institute of Marine Sciences \& Fisheries, University of Chittagong, Bangladesh \\ ${ }^{3}$ Bangladesh Fisheries Research Institute, Cox's Bazar, Bangladesh \\ *Corresponding Author E-mail: taruimscu@gmail.com
}

\begin{abstract}
Macrobenthos always play a significant role in the food web of any coastal environment. It also uses as a good aquatic ecosystem health module indicators. The abundance and distributions of macrobenthos in Rezukhal, Cox's Bazar were conducted in relation to hydrological parameters. Samples were collected monthly during June-2015 to May-2016 from three separate stations use different scientific instruments at Rezukhal estuary. A total of 7662 individuals of macrobenthos were counted in total of III stations. Macrobenthos were comprised of six major groups namely Polychaeta (52.22-91.57\%), crustacean (3.79-8.09\%), Bivalvia (1.05$2.27 \%)$, Nemertia (0.79-1.60\%), Sipuncula $(0-8.55 \%)$ and Gastropoda (1.36-31.92\%). Total number of macrobenthos was higher at station I (4197 individuals $\mathrm{m}^{-2}$ ) and lower at station II (1186 individuals $\mathrm{m}^{-2}$ ) among three stations. The study revealed that highest no. of Macrobenthos were found in Post monsoon period about 3146 individuals $m^{-2}$ and lowest in Premonsoon period about 1995 individuals $\mathrm{m}^{-2}$ The average soil and water $P^{H}$ were found in monsoon (5.87\&7.45), Post monsoon (5.97\&7.28), Premonsoon (6.03\&7.33) respectively. The average salinity was found in monsoon (11.92ppt), Post monsoon (25.91ppt), Premonsoon (28.75ppt) respectively. The average spring tide and neap tide level were found in monsoon (15\&3.04 ft), Post monsoon (12.67\&1.36 ft), Premonsoon (11.28\&1.16 ft) respectively. The average soil and water temperature were found in monsoon $\left(28.67 \& 27.67^{\circ} \mathrm{C}\right)$, Post monsoon $\left(29.41 \& 28.5^{\circ} \mathrm{C}\right)$, Premonsoon $\left(29.42 \& 29.83^{\circ} \mathrm{C}\right)$ respectively. Soil moisture ranged was from 26.36-35.07\%. The highest organic carbon and organic matter concentration was observed at station I (2.58\%-4.3\%) and lowest at station II (1.59\%-2.96\%) respevtively. Maximum fraction of sand by weight was found at stations III (81.60\%) and II (76.78\%). While the highest fraction of clay (22.58\%) and silt (11.20\%) was recorded in stations I. It was observed that benthic organism's abundance and distribution pattern were influenced with clay and silt fraction of the sediments as well as hydrological factors.
\end{abstract}

Keywords: Mcarobenthos, Abundance, Distributions, Hydrology, Rezukhal, Cox's Bazar.

\section{Introduction}

Macrobenthos are invertebrates living in or on the sediments or attached to hard substrates. They are bio-indicators of specific environment and habitat conditions. They have important roles in food chain and recycling of organic matters, detoxifying pollutants, dispersion and burial and secondary production (Reish, 1960, 1967; Heilskov and Holmer, 2001; Blanchet et al., 2008; Kang et al., 2007; Dauvin, 2007; Bellan, 2008; Borja et al., 2008). Macro-benthos in estuarine ecosystem provides significant role to the aquatic food web. They contribute to ecosystem stability through the sustenance of fishery resources. The composition, abundance and distribution pattern of macrobenthos can act as an ecosystem index by indicating trophic structure, quality of water and the eutrophication level of the aquatic ecosystem(Mehedi et al, 2005). Hydrological parameter of the environment may influence macro-benthic organisms either positively or negatively depending on their sources. Excessive input of nutrients and changes of soil parameters can cause long or short-term shifts in benthic species composition, abundance and richness (Aura et al, 2011). Benthic faunas developed naturally in aquatic ecosystems. Besides the trophic relationship with microbes, they have important roles in estuarine ecosystem, specially with regards to food supply, productivity, fish growth and nutrient cycling. The compositions in the estuarine ecosystems depends on several factors like siltation, water quality, sediment condition and temperature. Previous studies revealed that the macrobenthos were essential for many estuarine species i.e, fishes, shelfish and avifauna through their entire life stages. A number of studies argued that the richest fisheries of the world are closely related to the benthic community, particularly demersal fishes and shrimps are closely related to the benthic communities as their major source of food (Longhurst, 1957, Chong and Sasekumar, 1974). Longhurst (1957) investigated the relationship between demersal fishes and soft bottom 
benthos in the West African estuary and food that macro invertebrates are the main diet for the demersal fisheries. Benthic fauna can influence water chemistry, regulate sediment properties and control nutrient cycle by mobilizing and rearticulating sediment and organic matter (Coull, 1970). Many literatures are available on the descriptive and correlative studies of benthic faunal taxa with environmental factors (Coull,1970). Benthic organisms may be dependent on textural composition of estuarine sediments that might limit the distributions of certain organisms (Davis, 1971). However, there are a very few study on macrobenthos composition and abundance in the estuarine channel system in Bangladesh. Therefore, the main objectives of this study was to investigate the macrobenths distribution and their abundance in the estuarine system of Rezukhal estuary of cox's Bazar. Several hydrological parameters of soil and water were also investigated to understand the relationship between some hydrological parameters and the macrobenthos composition in this estuarine system.

The objectives of this study were-

\section{Objectives}

$\checkmark \quad$ To asses the abundance and distribution of macro-benthic faunal community of the study area.

$\checkmark$ To assess the hydrological factors (Water $\mathrm{pH}$,Temperature, Salinity, Water transparency, Dissolved Oxygen, Tidal elevation, organic matter, Soil $\mathrm{P}^{\mathrm{H}}$, soil Temperature, Soil Moisture, organic Matter, Organic Carbon, Sand\%, Silt\%,Clay\%) of the Rezu Khal of Cox's Bazar coast.

$\checkmark$ To see the interrelation of hydrological factors with the abundance and distribution of macro-benthos community.

\section{Study Area}

The Rezukhal estuary is located at south-eastern coast of the Bay of Bengal. This estuary is relatively narrow (about 16km) but has great importancy compared to other estuary of the Cox's Bazar district. Rezukhal estuary has a semidiurnal tidal regime and heavily influenced by monsoon period. The tidal range of Rezukhal estuary varied between $1.05 \mathrm{ft}$ and $17.1 \mathrm{ft}$ during neap and spring tide respectively. The estuarine zone is also characterized by long intertidal mudflats where mangrove vegetation (Avicennia alba, Avicennia marina, Nypa fruticans), macro algae (Ulva intestinalis), salt tolerant grass Imperata cylindrical, cord grass Portesia sp.and seagrass Halophila beccarii are present. The upper part of this estuary is heavily influenced by fishing activities. It is also known as a good nursery ground for various fishery species. Different gears are used for catching fish. Three sampling stations were selected for the present study namely Station I (Niribili Hatchery Zone), Station II (Sonarpara) and station III (Chowdhury para). The distance from one station to other stations was about $3 \mathrm{~km}$.

\section{Materials And Methods}

For Collection of macrobenthos using an Ekman Berge bottom grab $\left(0.04 \mathrm{~m}^{2}\right)$ and sampling were conducting every month during June 2015 to May 2016. Three samples were collected from each station with three replicates. Samples were sieved through $500 \mu \mathrm{m}$ mesh and the remaining was fixed with formaldehyde with some rose Bengal and transferred to Bangladesh Oceanographic Research Institute (BORI) Laboratory. Organisms were counted and sorted to major taxonomic groups. The major taxonomic group of benthos was identified following the references described by Amold and Britles (1989), Chuang (1961), Berry (19720, Lim (1963), Huys et al., (1996), Day (1967) and Fauchald (1977).

Hydrological parameters such as water \& soil temperature (Zeal,UK), Water $\mathrm{P}^{\mathrm{H}}$,Salinity, DO, Conductivity, TDS (Pro Plus, YSI, USA), soil $\mathrm{P}^{\mathrm{H}} \&$ Soil moisture (PAL Soil, Japan) were recorded in the field respectively. Soil samples were collected from each station with 3 replicates using grab sampler from a depth of $0-10 \mathrm{~cm}$ and the samples were kept in self sealed plastic bags.

Analysis of total organic matter (TOM) was carried out by burning sediment in furnace at $450^{\circ} \mathrm{c}$ for 5 h. (Neria and Hopner, 1994). For determination of Soil texture was measured following the procedure described by Bouyoucos (1962). Soil organic matter was detected following procedure described by Boyd (1995). Soil organic carbon was calculated dividing the organic matter by a factor of 1.9 following the procedure described by Nelson and Sommers (1982).Sediment grain size analysis was carried out with a laser-based particle size analyzer (LA-950, Horiba). The mean density of each group in each station was calculated from the estimates of total density in each station. Plots of average abundance of major faunal groups were depicted in EXCEL2007.

\section{Results}

A total of 7662 individuals of macrobenthic invertebrates were counted in total of 3 stations. The total number of macrobenthos at station I (4197 individual's $\left.\mathrm{m}^{-2}\right)$ and station II (1186 individual's $\left.\mathrm{m}^{-2}\right)$ and Station III (2279 individuals $\mathrm{m}^{-2}$ ). The major groups of macrobenthos were comprised of the Polychaeta,Crustacea, Bivalvia, Nemertia, Sipuncula and Gastropoda. The density range of macrobenthos were Polychaeta (1003-2192 individuals $\mathrm{m}^{-2}$ ), Nemertia (18-56 individuals $\left.\mathrm{m}^{-2}\right)$, Crustaceans $\left(\mathbf{9 6 - 1 5 9}\right.$ individuals $\left.\mathrm{m}^{-2}\right)$, Bivalvia (24-91 individuals $\left.\mathrm{m}^{-2}\right)$,Sipuncula $\left(\mathbf{0 - 3 5 9}\right.$ individuals $\left.\mathrm{m}^{-2}\right)$ and Gastropoda $\left(\mathbf{3 1 - 1 3 4 0}\right.$ individuals $\left.\mathrm{m}^{-2}\right)$ Table1.In terms of 
percentage composition of macrobenthos, the figures recorded were 52.22-91.57\%, 3.79-8.09\%,1.05$2.27 \%, 0.79-1.60 \%, 0-8.55 \%, 1.36-31.92 \%$ for Polychaeta, Crustacea, Bivalvia, Nemertia, Sipuncula and Gastropoda respectively (Table 1).

Table1: Abundance of macrobenthos (individuals $\mathrm{m}^{-2}$ ) recorded (June-May) from the Rezukhal estuary system, Cox's Bazar.

\begin{tabular}{|l|l|l|l|l|l|l|l|}
\hline SI & Group & Station-I & $\%$ & Station-II & $\%$ & Station-III & $\%$ \\
\hline 1 & Polychaeta & 2192 & 52.22 & 1003 & 84.56 & 2087 & 91.57 \\
\hline 2 & Crustacea & 159 & 3.79 & 96 & 8.09 & 119 & 5.22 \\
\hline 3 & Bivalve & 91 & 2.17 & 27 & 2.27 & 24 & 1.05 \\
\hline 4 & Nemertia & 56 & 1.33 & 19 & 1.60 & 18 & 0.79 \\
\hline 5 & Sipuncula & 359 & 8.55 & 0 & 0 & 0 & 0 \\
\hline 6 & Gastropoda & 1340 & 31.92 & 41 & 3.45 & 31 & 1.36 \\
\hline & Total & 4197 & 1186 & 2279 & \\
\hline
\end{tabular}

Table 2. Benthic Data at Monsoon (June-Sept) Period:

\begin{tabular}{|c|c|c|c|c|c|c|c|c|c|c|}
\hline \multirow[t]{2}{*}{ SI } & \multirow[t]{2}{*}{ Group } & \multicolumn{3}{|l|}{ Station-I } & \multicolumn{3}{|l|}{ Station-II } & \multicolumn{3}{|l|}{ Station-III } \\
\hline & & Monthwise data & Total & Avg. & Monthwise data & Total & Avg. & Monthwise data & Total & Avg. \\
\hline 1 & Polychaeta & $137,141,259,168$ & 705 & 176.25 & $56,15,124,32$ & 227 & 56.75 & $77,83,170,290$ & 620 & 155 \\
\hline 2 & Crustacea & $17,7,14,9$ & 47 & 11.75 & $11,3,3,9$ & 26 & 6.5 & $1,8,7,9$ & 25 & 6.25 \\
\hline 3 & Bivalve & $6,12,14,8$ & 40 & 10 & $2,1,1,2$ & 6 & 1.5 & $1,1,2,1$ & 5 & 1.25 \\
\hline 4 & Nemertia & $3,2,0,0$ & 5 & 1.25 & $1,1,0,6$ & 8 & 2 & $2,2,3,1$ & 8 & 2 \\
\hline 5 & Sipuncula & $17,62,38,72$ & 189 & 47.25 & $0,0,0,0$ & 0 & 0 & $0,0,0,0$ & 0 & 0 \\
\hline 6 & Gastropoda & $158,140,188,112$ & 598 & 149.5 & $2,1,2,2$ & 7 & 1.75 & $1,1,2,1$ & 5 & 1.25 \\
\hline & & Total & 1584 & & Total & 274 & & Total & 663 & \\
\hline
\end{tabular}

Table 3. Benthic Data at Post Monsoon (Oct-January) Period:

\begin{tabular}{|c|c|c|c|c|c|c|c|c|c|c|}
\hline \multirow[t]{2}{*}{ SI } & \multirow[t]{2}{*}{ Group } & \multicolumn{3}{|l|}{ Station-1 } & \multicolumn{3}{|l|}{ Station-2 } & \multicolumn{3}{|l|}{ Station-3 } \\
\hline & & Monthwise data & Total & Average/month & Monthwise data & Total & Average & Monthwise data & Total & Average \\
\hline 1 & Polychaeta & $386,297,152,147$ & 982 & 245.5 & $284,17,178,66$ & 545 & 136.25 & $290,394,253,13$ & 950 & 237.5 \\
\hline 2 & Crustacea & $28,17,11,5$ & 61 & 15.25 & $5,12,8,13$ & 38 & 9.5 & $9,4,7,23$ & 43 & 10.75 \\
\hline 3 & Bivalve & $11,5,3,7$ & 26 & 6.5 & $1,2,6,2$ & 11 & 2.75 & $1,2,2,3$ & 8 & 2 \\
\hline 4 & Nemertia & $0,0,0,3$ & 3 & 0.75 & $0,1,1,2$ & 4 & 1 & $1,1,1,2$ & 5 & 1.25 \\
\hline 5 & Sipuncula & $27,23,3,18$ & 71 & 17.75 & $0,0,0,0$ & 0 & 0 & $0,0,0,0$ & 0 & 0 \\
\hline 6 & Gastropoda & $155,38,33,150$ & 376 & 94 & $2,3,2,7$ & 14 & 3.5 & $2,3,2,2$ & 9 & 2.25 \\
\hline & & Total & 1519 & & Total & 612 & & Total & 1015 & \\
\hline
\end{tabular}

Table 4. Benthic Data at Pre monsoon (February-May) Period:

\begin{tabular}{|c|c|c|c|c|c|c|c|c|c|c|}
\hline \multirow[t]{2}{*}{ SI } & \multirow[t]{2}{*}{ Group } & \multicolumn{3}{|l|}{ Station-I } & \multicolumn{3}{|l|}{ Station-II } & \multicolumn{3}{|l|}{ Station-III } \\
\hline & & Monthwise data & Total & $\begin{array}{l}\text { Average/ } \\
\text { month }\end{array}$ & $\begin{array}{l}\text { Monthwise } \\
\text { data }\end{array}$ & Total & Average & $\begin{array}{l}\text { Monthwise } \\
\text { data }\end{array}$ & Total & Average \\
\hline 1 & Polychaeta & $98,52,225,130$ & 505 & 126.25 & $111,54,29,37$ & 231 & 57.75 & $83,260,76,98$ & 517 & 129.25 \\
\hline 2 & Crustacea & $14,10,13,14$ & 51 & 12.75 & $7,7,8,10$ & 32 & 8 & $13,20,11,7$ & 51 & 12.75 \\
\hline 3 & Bivalve & $8,5,5,7$ & 25 & 6.25 & $3,2,2,3$ & 10 & 2.5 & $2,3,4,2$ & 11 & 2.75 \\
\hline 4 & Nemertia & $1,2,35,10$ & 48 & 12 & $1,1,3,2$ & 7 & 1.75 & $1,1,2,1$ & 5 & 1.25 \\
\hline 5 & Sipuncula & $54,17,16,12$ & 99 & 24.75 & $0,0,0,0$ & 0 & 0 & $0,0,0,0$ & 0 & 0 \\
\hline 6 & Gastropoda & $66,42,133,125$ & 366 & 91.5 & $4,2,7,7$ & 20 & 5 & $3,3,5,6$ & 17 & 4.25 \\
\hline & & Total & 1094 & & Total & 300 & & Total & 601 & \\
\hline
\end{tabular}

The average soil and water $\mathrm{P}^{\mathrm{H}}$ were found in monsoon (5.87\&7.45), Post monsoon (5.97\&7.28), Premonsoon (6.03\&7.33) respectively (Table 5, 6, 7). The average salinity was found in monsoon (11.92ppt), Post monsoon (25.91ppt), Premonsoon (28.75ppt) respectively. The average spring tide and neap tide level were found in monsoon (15\&3.04 ft), Post monsoon (12.67\&1.36 ft), Premonsoon (11.28\&1.16 ft) respectively.

The average soil and water temperature were found in monsoon $\left(28.67 \& 27.67^{0} \mathrm{c}\right)$, Post monsoon $\left(29.41 \& 28.5^{0} \mathrm{c}\right)$, Premonsoon $\left(29.42 \& 29.83^{\circ} \mathrm{c}\right)$ respectively (Table 5, 6, 7).

Table 5. Hydrological data at Monsoon (June-sept.) Period:

\begin{tabular}{|c|c|c|c|c|c|c|c|c|c|c|}
\hline \multirow{2}{*}{\begin{tabular}{l|}
$\mathrm{S}$ \\
$\mathrm{I}$ \\
\end{tabular}} & \multirow{2}{*}{ Parameter Name } & \multicolumn{3}{|c|}{ Station-I } & \multicolumn{3}{|c|}{ Station-II } & \multicolumn{3}{|c|}{ Station-III } \\
\hline & & Month wise data & Total & Avg. & & Total & Avg. & & Total & Avg. \\
\hline 1 & Water temperature $\left({ }^{\circ} \mathrm{c}\right)$ & $27,26,27,28$ & 108 & 27 & $29,26,28,29$ & 112 & 28 & $32,26,27,27$ & 112 & 28 \\
\hline 2 & Soil temperature $\left({ }^{\circ} \mathrm{c}\right)$ & $28,27,28,29$ & 112 & 28 & $30,27,29,30$ & 116 & 29 & $32,27,28,28$ & 116 & 29 \\
\hline 3 & Water $\mathrm{P}^{\mathrm{H}}$ & $7.4,7.5,7.4,7.4$ & 29.8 & 7.45 & $7.2,7.2,7.6,7.6$ & 29.6 & 7.4 & $7.2,7.8,7.6,7.6$ & 30.2 & 7.55 \\
\hline 4 & Soil $\mathrm{P}^{\mathrm{H}}$ & $6.4,6,6.2,6.4$ & 25 & 6.25 & $5.8,5.8,5.6,5.8$ & 23 & 5.75 & $5.8,5.4,5.2,5.6$ & 22 & 5.5 \\
\hline 5 & Salinity (ppt) & $16,15,17,18$ & 66 & 16.5 & $16,7,10,12$ & 45 & 11.25 & $24,2,2,4$ & 32 & 8 \\
\hline 6 & High Tide level (ft) & $16,18,16.6,17.8$ & 68.4 & 17.1 & $14.7,14.5,17.7,14.3$ & 61.2 & 15.3 & $10.2,13.2,13.6,13.4$ & 50.4 & 12.6 \\
\hline 7 & Low tide level (ft) & $1.8,4,3.8,4.8$ & 14.4 & 3.6 & $1.8,3.5,3.8,3.6$ & 12.7 & 3.17 & $1,2,3.2,3.2$ & 9.4 & 2.35 \\
\hline 8 & Transparency $(\mathrm{cm})$ & $36,28,32,34$ & 130 & 32.5 & $39,28,29,30$ & 126 & 31.5 & $67,31,32,31$ & 161 & 40.25 \\
\hline
\end{tabular}


Table 6. Hydrological data at Post Monsoon (Oct-Jan) Period:

\begin{tabular}{|c|c|c|c|c|c|c|c|c|c|c|}
\hline \multirow{2}{*}{$\begin{array}{l}\mathrm{S} \\
\mathrm{I}\end{array}$} & \multirow[t]{2}{*}{ Parameter Name } & \multicolumn{3}{|c|}{ Station-I } & \multicolumn{3}{|c|}{ Station-II } & \multicolumn{3}{|c|}{ Station-III } \\
\hline & & & Total & Avg. & & Total & Avg. & & Total & Avg. \\
\hline 1 & Water temp. $\left({ }^{\circ} \mathrm{c}\right)$ & $31,31,29,28$ & 119 & 29.75 & $31,30,25,28$ & 114 & 28.5 & $31,27,24,27$ & 109 & 27.25 \\
\hline 2 & Soil temp. $\left({ }^{\circ} \mathrm{c}\right)$ & $32,33,30,29,25$ & 124 & 31 & $34,31,26,27$ & 118 & 29.5 & $32,30,24,25$ & 111 & 27.75 \\
\hline 3 & Water $\mathrm{P}^{\mathrm{H}}$ & $7.2,6.8,7.4,7.6$ & 29 & 7.25 & $7.0,7.4,6.8,7.4$ & 28.6 & 7.15 & $7.6,7.4,7.2,7.6$ & 29.8 & 7.45 \\
\hline 4 & Soil $\mathrm{P}^{\mathrm{H}}$ & $6.2,5.8,5.2,6.0$ & 23.2 & 5.8 & $6,6.2,6.2,6.2$ & 24.6 & 6.15 & $5.2,6.3,6.4,6$ & 23.9 & 5.98 \\
\hline 5 & Salinity (ppt) & $28,30,32,32$ & 122 & 30.5 & $26,27,27,28$ & 108 & 27 & $17,18,22,24$ & 81 & 20.25 \\
\hline 6 & High Tide level $(\mathrm{ft})$ & $15.4,15.2,14.8,14.6$ & 60 & 15 & $12,14,10.6,11.2$ & 47.8 & 11.95 & $11.8,11.2,10.8,10.5$ & 44.3 & 11.07 \\
\hline 7 & Low tide level $(\mathrm{ft})$ & $2.3,1.3,1,1$ & 5.6 & 1.4 & $1.8,1.8,1.2,1.2$ & 6 & 1.5 & $1.2,1.3,1.2,1$ & 4.7 & 1.17 \\
\hline 8 & Transparency $(\mathrm{cm})$ & $65,67,65,65$ & 262 & 65.5 & $48,48,75,76$ & 247 & & $45,54,70,58$ & 227 & 56.75 \\
\hline
\end{tabular}

Table7. Hydrological data at Pre Monsoon (February-May) Period:

\begin{tabular}{|c|c|c|c|c|c|c|c|c|c|c|}
\hline $\mathrm{S}$ & \multirow[t]{2}{*}{ Parameter Name } & \multicolumn{3}{|c|}{ Station-I } & \multicolumn{3}{|c|}{ Station-II } & \multicolumn{3}{|c|}{ Station-III } \\
\hline I & & & Total & Avg. & & Total & Avg. & & Total & Avg. \\
\hline 1 & Water temp. $\left({ }^{\circ} \mathrm{c}\right)$ & $26,32,33,31$ & 122 & 30.5 & $25,30,32,32$ & 119 & 29.75 & $26,28,32,31$ & 117 & 29.25 \\
\hline 2 & Soil temp. $\left({ }^{\circ} \mathrm{c}\right)$ & $25,31,32,33$ & 121 & 30.25 & $23,29,31,31$ & 114 & 28.5 & $26,30,32,30$ & 118 & 29.5 \\
\hline 3 & Water $\mathrm{P}^{\mathrm{H}}$ & $7.2,7.4,7.2,7.4$ & 29.2 & 7.3 & $7.6,7.6,6.8,7.0$ & 29 & 7.25 & $7.6,7.6,7.2,7.4$ & 29.8 & 7.45 \\
\hline 4 & Soil $\mathrm{P}^{\mathrm{H}}$ & $5.8,5.8,6.0,6.2$ & 23.8 & 5.95 & $6.2,6.2,6.4,6.0$ & 24.8 & 6.2 & $6,6,5.8,6$ & 23.8 & 5.95 \\
\hline 5 & Salinity (ppt) & $31,32,33,33$ & 129 & 32.25 & $29,29,28,29$ & 115 & 28.75 & $27,25,24,25$ & 101 & 25.25 \\
\hline 6 & High Tide level (ft) & $13.8,12.6,12,12.2$ & 50.6 & 12.65 & $10.6,10.8,10.6,11$ & 43 & 10.75 & $10.4,10.2,10.8,10.4$ & 41.8 & 10.45 \\
\hline 7 & Low tide level $(\mathrm{ft})$ & $1,1,1.2,1.8$ & 5 & 1.25 & $1.3,1.2,1,1.2$ & 4.7 & 1.17 & $1,1.2,1,1$ & 4.2 & 1.05 \\
\hline 8 & Transparency $(\mathrm{cm})$ & $67,71,74,72$ & 284 & 71 & $70,72,69,70$ & 281 & 70.25 & $64,64,67,69$ & 264 & 66 \\
\hline
\end{tabular}

Soil moisture ranged was from 26.36-35.07\%. The highest organic carbon concentration was observed at station I $(2.58 \%)$ and lowest at station II $(1.59 \%)$. Maximum fraction of sand by weight was found at stations III $(81.88 \%)$ and II $\mathbf{( 7 6 . 7 8 \% )}$. While the highest fraction of clay $(22.58 \%)$ and silt $(11.20 \%)$ were recorded in stations I (Table 8).

Table 8: Soil parameters of Rezukhal estuary system, Cox’s Bazar

\begin{tabular}{|l|l|l|l|l|}
\hline SI & Parameter & Station-1 & Station-2 & Station-3 \\
\hline 1 & Soil $\mathrm{P}^{\mathrm{H}}$ & 6.4 & 6.30 & 6.10 \\
\hline 2 & Soil Moisture\% & 35.07 & 28.63 & 26.36 \\
\hline 3 & Organic Matter\% & 4.3 & 3.45 & 2.96 \\
\hline 4 & Organic Carbon\% & 2.58 & 1.82 & 1.59 \\
\hline 5 & Sand\% & 66.22 & 76.78 & 81.60 \\
\hline 6 & Silt\% & 11.20 & 7.50 & 4.67 \\
\hline 7 & Clay\% & 22.58 & 15.72 & 13.73 \\
\hline
\end{tabular}

\section{Discussion}

The present study demonstrated that abundance of polychaetes was higher than other groups followed by crustaceans, Gastropods, bivalves, nemertia and sipunculas. The abundance of polychaetes and gastropods was higher in the stations I due to higher input of nutrients from the sediments, the habitat and environmental condition. Generally, relatively soft surface and high detritus or organic carbon $(>3 \%)$ in these stations may cause for high food diversity hence supports greater benthic organisms (Arshad et al., 2011; Aura et al., 2011). This result mirrored the findings of other studies in which polychaetes, bivalves, crustaceans were the most abundant group in the Bakkhali Channel system, Cox's Bazar (Abu Hena etal., 2012). These species are common in the coastal seagrass and mangrove habitats. The number of macrobenthos group observed in the present study is similar to the number of groups encountered in other tropical tidal areas (Aura et al., 2011). Environmnetal factors such as sediment type, temperature, salinity, primary productivity, depth, etc. are known to influence the structure of macrobenthos assemblages (Basson et al., 1977).The result of Spearman's correlation analysis demonstrated that sediment temperature, depth and TOM were highly correlated with benthic macroinvertebrates assemblages. Likewise, Al-Yamani et al., (2012) stated that factors like depth, temperature and salinity, and type sediment texture as the main factors that determined the benthic community structure. Depth as an important factor on shaping macrobenthos assemblages especially mollusks (Rabey et al., 1994; Gasper et al., 2002; Greenstreet et al., 2006; Mutlu and Ergev, 2008; Mutlu et al., 2010; Mutlu and Ergev, 2012). Polychaetes play an important role in the functioning of benthic communities (Hutchings, 1998).Polychaetes are also important in environmental monitoring studies because of their sensitivity to the pollution (Giangrande et al., 2005). Among three sampling locations, stations I observed to have a higher fraction of clay and silt than the other stations. Usually, soil condition or sediment particles are important parameter to colonize the benthic fauna in the estuarine environment (Chou et al., 2004). Sedimentation not only affects faunal communities in the estuarine ecosystem but also changes sediment composition, organic matter 
and nutrient input. The present study showed that the abundance and distribution of benthic fauna diversity was higher in the areas where organic matter is rich.

\section{VII.Conclusion}

This study revealed that the abundance and distribution of macrobenthic invertebrates depends on soft sediment surface and concentration of high detritus and organic matter. Benthic macro invertebrate's species assemblages are comparatively higher in station I than in station II and III. The maximum abundance of macrobenthos was related to nutrients input and sediment texture quality in this estuary system. However, the lower abundance of macroenthos probably due to continuous environmental disturbance likes sedimentation, hard sediment surface and pollution in this estuary system which might badly affect in the estuarine ecosystem. With increasing rate of the environmental variations in the Rezukhal estuary such as temperature and salinity, constructions, dams or manmade barrier, habitats, and lack of accurate information on benthic communities, it is necessary to support conservation and proper management of this unique ecosystem. From the present study, it could be concluded that the hydrography, nutrients, and sediment texture are the major factors responsible for fluctuation in benthic macrofaunal assemblages in the study area. Therefore, there is an urgent need for more study in benthic-pelagic coupling, secondary production of macroinfauna and meiofauna, trophic studies and interactions among groups.

\section{Reference}

[1]. Reis, D.J., 1960. The use of marine invertebrates as indicators of water quality. In: Pearson, E.A. (ed.) Procedings of the first international conference on waste disposal in the marine environment. Pergamo Press, New Yprk, 92-103 pp.

[2]. Reis, D.J., 1967. Relationship of polychaetes to varying dissolved osygen concentrations. In: Marota, J.P., Josa, R. (ed.) Proceedings of the third international conference on water pollution research. Water Pollution Control Federation, Washington, D.C., 199-216pp.

[3]. Heilskov, A.C and Holmer, M., 2001. Effects of benthic fauna on organic matter mineralization in fish-farm sediments: importance of size and abundance. ICES Journal of Marine Science, 58:427-434.

[4]. Blanchet, H., Lavesque, N., Ruellet, T., Dauvin, J.c., Sauriau, P.G., Desroy, N., Desclaux, C., Leconte, M., Bachelet, G., Janson, A.-L., Bessineton, C., Duhamel, S., Jourde, J., Mayot, S., Simon, S. and de Montaudouin, X., 2008. Use of biotic indices in semienclosed coastal ecosystems and transitional waters habitat implications for the implementations of the European Water Framework Directive. Ecological Indicators, 8(4): 360-372.

[5]. Kang, C.K., Choy, E.J., Paik, S.K., Park, H.J., Lee, K.S. and An, S., 2007. Contributions of primaryorganic matter sources to macroinvertebrate production in an intertidal saltmarsh (Scirpu striqueter) ecosystem. Marine Ecology-Progress Series, 334: 131143.

[6]. Dauvin, J.C and Ruellet, T., 2007. Polychaete/amphipod ratio revisited. Marine Pollution Bulletin, 55:215-224.

[7]. Bellan, G., 2008. Pollution indices. Encyclopedia of Ecology, 2861-2868.

[8]. Borja, A., Dauer, D.M., Diaz, R., Llanso, R.J., Muxika, I., Rodriguez, J.G. and Schaffner, L., 2008. Assessing estuarine benthic quality conditions in Chesapeake Bay: A comparison of three indices. Ecological Indicators, 8:395-403.

[9]. Mehedi, M.D., F.A. Bhat and A.R. Yousuf, 2005. Ecology of macro zoobenthos in Rambiara stream. Kashmir J.Res.Dev., 5:95-100.

[10]. Aura, C.M., P.O. Raburu and J. Herrmann, 2011. Macro invertebrate's community structure in Rivers Kipkaren and Sosiani, River Nzoia basin, Kenya. J.Eco.Nat. Environ., 3:39-46.

[11]. Longhurst, A.R., 1957. An Ecological Survey of the West African Marine Benthos. Fishery Publication, London, Pages: 102.

[12]. Chong, V.C. and A. Sasekumar, 1974. Distribution of macro fauna on a Malayan mangrove shore. J. Ani. Eco., 43: 51-69.

[13]. Coull. B.C., 1970.Shallow water meiobenthos of the Bermuda platform. Oecologia (Berlin), 4:325-357.

[14]. Davis, H.C., 1971. On food and feeding of larva of the American system Crassostrea virginica. Biol. Bull. Mar., 104:334-350.

[15]. Amold, P.W. and R.A. Birtles, 1989. Soft Sediment Marine Invertebrates of Southeast Asia and Australia: A Guide to Identification. Australian Institute of Marine Sciences, Townville, Pages: 272.

[16]. Chuang, S.H., 1961. On Malayan Shores. Caslon Printers Ltd., Singapore, Pages: 225.

[17]. Berry A.J., 1972. The natural history of West Malaysian mangrove faunas. Mal. Nat. J., 25: 135-162.

[18]. Lim, C.F., 1963. A preliminary illustrated account mangrove mollusks from Singapore and South-West Malaya. Malayan Nat. J., 17: $235-240$

[19]. Huys, R., J.M. Gee, C.G. Moore and R. Hamond, 1996. Marine and Brackish Water Harpacticis Copepodes. In: Synopses of British Fauna (New Series), Barnes, R.S. and J.H. Crothers, (Eds.). The Linnean Society of London and the Estuarine and Coastal Science Association, London, Uk., Pages: 352.

[20]. Fauchald, K., 1977. The polychaete worms, definitions and keys to the orders, families and Genera. Natuarl History Museum of Los Angles County.

[21]. Neria, C and Hopner, T., 1994. The role of Heteromastus filiformis (Capitellidae, polychaeta) in organic carbon cycling. Ophelia. 39(1): 55-73.

[22]. Bouyocous, G.J., 1962. Hydrometer method improved for making particle size analysis of soils. Agron. J., 54: 464-465.

[23]. Boyd, C.E., 1995. Bottom Soils, sediment and Pond Aquaculture. Chapman and Hall, New York, USA., ISBN: 0412069415, pp: 348.

[24]. Nelson, D.W. and L.E. Sommers, 1982. Total Carbon, Organic Carbon and Organic Matter. In: Methods of Soil Analysis. Part 2 Chemical and Microbiological Properties Agronimy, Page, A.L., R.H. Miller and D.R. Keeney (Eds.). $2^{\text {nd }}$ Edn., ASA-SSSA, Madison, Wisconsin, USA., pp: 539-579.

[25]. Arshad, A., R. Ara, S.M.N. Amin, M.Effendi, C.C. Zaidi and A.G. Mazlan, 2011. Influence of environmental parameters on shrimp post-larvae in the Sungai Pulai seagrass beds of Johor Strait, Peninsular Malaysia. Sci.Res.Essays, 6: 5501-5506.

[26]. Abu, H.M.K, S.M.S. Kohinoor, M.A.M. Siddique, J. Ismail, M.H. Idris and S.M.N. Amin, 2012. Composition of Macrobenthos in the Bakkhali Channek System, Cox’s Bazar with Notes on Soil Parameter. Pakistan Journal of Biological Sciences 15 (13): 641 646, 2012. 
[27]. Basson, P., Burchard, J., Hardy, J. and Price, A., 1977. Biotops of the western Persian Gulf. Marine Life; Environments of Saudi Arabia. Dhahran, Saudi Arabia: Aramco Department of Loss Prevention; Environmental Affairs Publishers, 284 P.

[28]. Al-Yamani, F.Y., Skryabin, V., Boltachova, N., revkov, N., Makarov, M., Grinstov, V. and Kolesnikova, E., 2012. Illustrated Atlas on the Zoobenthos of Kuwait. Kuwait Institute for Scientific Research. $401 \mathrm{P}$.

[29]. Raby, D., Lagadeuc, Y., Dodson, J. and Mingelbier, M., 1994. Relationship between feeding and vertical distribution of bivalve larvae in stratified and mixed waters. Marine Ecology Progress Series, 103: 275-284.

[30]. Gasper, M.B., Leita, O,F., Santos, M.N., Sobral, M., Chi charo, L., Chi charo, A. and Monteiro, C., 2002. Influence of mesh size and tooth spacing on the proportion of damaged organisms in the catches of the Portuguese clam dredge fishery. ICES Journal of Marine Science, 59: 1228-1236.

[31]. Greenstreet, SPR., Armstrong, E., Mosegaard, H. and Jensen, H., 2006. Variation in the abundance of sand eels Ammodytes marinus of southeast Scotland: an evaluation of area-closure fisheries management and stock abundance assessment methods. ICES Journal of Marine Science, 63: 1530-1550.

[32]. Mutlu, E. and Ergev, M.B., 2008. Spatio-temporal distribution of soft-bottom epibenthic fauna on the Cilician shelf (Turkey), Mediterranean Sea Revista de Biologia Tropical, 56: 1919-1946.

[33]. Mutlu, E., Cinar, M.E. and Ergev, M.B., 2010. Distribution of soft-bottom polychaetes of the Levantine coast of Turkey, eastern Mediterranean Sea. Journal of Marine Systems, 79 (1-2): 23-35.

[34]. Hutchings, P., 1998. Biodiversity and functioning of polychaetes in benthic sediments. Biodiversity and Conservation, 7: 11331145 .

[35]. Giangrande, A., Licciano, M. and Musco, L., 2005. Polychaetes as environmental indicators revisited. Marine Pollution Bulletin, 50 (11): 1153-1162.

[36]. Chou, L.M., J.Y. Yu and T.L. Loh, 2004. Impacts of sediments on the soft bottom benthic communities in the southern islands of Singapore. Hydrobiologia, 515: 91-106. 